SAINS TANAH - Journal of Soil Science and Agroclimatology

Journal homepage: http://jurnal.uns.ac.id/tanah

\title{
The comparison between conventional and rice ratoon system on soil properties, rice productivity and nutrient status
}

\author{
Muchammad Bima Gegana Sakti ${ }^{1}$, Komariah ${ }^{2 *}$, Dwi Priyo Ariyanto ${ }^{2}$, Sumani ${ }^{2}$, Muhamad Khoiru Zaki ${ }^{3}$, \\ Keigo Noda ${ }^{4}$ \\ ${ }^{1}$ Master Program of Soil Science Department, Graduate School, Sebelas Maret University, Surakarta, Indonesia \\ ${ }^{2}$ Department of Soil Science, Faculty of Agriculture, Sebelas Maret University, Indonesia \\ ${ }^{3}$ The United Graduate School of Agricultural Sciences, Gifu University, Japan \\ ${ }^{4}$ Faculty of Applied Biological Science, Gifu University, Japan
}

\begin{tabular}{|c|c|}
\hline ARTICLE INFO & ABSTRACT \\
\hline $\begin{array}{l}\text { Keywords: } \\
\text { Ratoon } \\
\text { Conventional } \\
\text { SINGGANG } \\
\text { SALIBU } \\
\text { Rice productivity } \\
\text { Article history } \\
\text { Submitted: 2021-01-12 } \\
\text { Accepted: 2021-04-20 } \\
\text { Available online: 2021-06-30 } \\
\text { Published regularly: June 2021 } \\
\text { * Corresponding Author } \\
\text { Email address: } \\
\text { komariah@staff.uns.ac.id }\end{array}$ & $\begin{array}{l}\text { Ratoon system is a method of rice cultivation that produces new tillers after the mother } \\
\text { plant is harvested and is continued by maintaining and caring for the shoots of the mother } \\
\text { plant. In Indonesia, SALIBU and SINGGANG, which are types of rice ratooning, have been } \\
\text { developed for Sumatra and Java regions, respectively. SALIBU is an innovation or a } \\
\text { modification of the rice ratoon system that focuses on maintaining the time of fertigation } \\
\text { and cutting of plant height. SINGGANG, on the other hand, is a rice ratoon system in which } \\
\text { the management of fertigation and cutting is not considered. Both systems have not yet } \\
\text { been implemented outside their places of origin. This study aims to compare the } \\
\text { conventional and modified rice ratoon systems considering parameters such as soil } \\
\text { properties, nutrient uptake, and the growth and yield of rice. The effects of rice ratoon } \\
\text { systems (SALIBU and SINGGANG), soil types (Inceptisols, Alfisols, and Vertisols), and } \\
\text { cultivars (Pandan Wangi and Mekongga) were evaluated. All treatments were evaluated in } \\
\text { a completely randomized design with three replicates in the net house. The results showed } \\
\text { that the soil porosity in SINGGANG (48.89\%) and SALIBU ( } 46.78 \% \text { ) systems were higher } \\
\text { than the conventional system (43.17\%) in the Inceptisols and Pandan Wangi cultivars. } \\
\text { Moreover, SINGGANG had a positive effect on the physical properties of soil (porosity and } \\
\text { permeability); whereas, SALIBU had a positive effect on the chemical properties of soil (pH } \\
\text { and organic carbon). In contrast, the agronomic parameters showed that the weights of } \\
\text { dry matter and dry yield for SINGGANG were } 44.96 \text { and } 23.09 \text { g per plant clump, } \\
\text { respectively, while those for SALIBU were } 55.54 \text { and } 25.74 \mathrm{~g} \text { per plant clump, respectively. } \\
\text { These were lower than the conventional system (63.18 and } 31.21 \mathrm{~g} \text { per plant clump, } \\
\text { respectively). Thus, we concluded that the SINGGANG and SALIBU ratoon systems had a } \\
\text { positive impact on soil properties, but both systems could not promote higher rice } \\
\text { production than the mother plant in all soil types and cultivars. }\end{array}$ \\
\hline
\end{tabular}

How to Cite: Sakti, M.B.G., Komariah, Ariyanto, D.P., Zaki, M.K., Noda, K. (2021). The comparison between conventional and rice ratoon system on soil properties, rice productivity, and nutrient status [Research]. Sains Tanah Journal of Soil Science and Agroclimatology, 18(1): 65-72. https://dx.doi.org/10.20961/stjssa.v18i1.47553

\section{Introduction}

The rice ratoon system has more advantages than the conventional rice cultivation system, including the minimized application of soil tillage (Fitri et al., 2019); conservation of water; reduction in agricultural inputs, such as labor input, maintenance costs, fertilizer costs, and weeding costs; and faster harvest times (Oad et al., 2002). However, the rice ratoon system has long been abandoned because it is considered unprofitable (Fitri et al., 2019). Therefore, to explore the potential of rice ratoon system, we compared it with the conventional rice cultivation system commonly used by most farmers in Indonesia (Susilawati et al., 2012). The use of the rice ratoon system can possibly solve the problem of limited water availability, which is the main problem in rainfed lands during the dry season and can increase rice 
production and cultivation (Imanudin et al., 2018). The rice ratoon system is a rice cultivation system that involves taking care of shoots of the mother plant that have previously been cut; these shoots are known as ratoon plants (Fitri et al., 2019). The rice ratoon system does not start from seeds, but from the shoots of the mother plant that have been cut. Therefore, it does not include the phases of soil tillage and seeding (Fitri et al., 2019). The rice ratoon systems that we used in this study were the SALIBU ratoon system, which originated from Western Sumatra, and the SINGGANG ratoon system, which originated from Central Java. The SALIBU is a rice ratoon system with special treatment at the time of cutting the shoots; whereas, the SINGGANG is a rice ratoon system without any special treatment (Fitri et al., 2019).

The rice ratoon system has the advantage of maintaining the physical and chemical properties of the soil, thus conserving it (Aula et al., 2019; Liu et al., 2014; Srivastava et al., 2009; Suwandi et al., 2012; Zhang et al., 2017). However, the rice ratoon system also has disadvantages: the productivity and plant nutrient uptake is lower than the conventional rice cultivation system (Ling et al., 2019; Liu, 2012; Sanni et al., 2009; Susilawati et al., 2012; Zhang et al., 2017). To date, only a few studies identified the soil properties alteration under rice ratooning cultivation, besides the productivity and yield. Hence, this research aims to compare the rice ratoon systems, which have been widely abandoned, with the conventional rice cultivation system with respect to parameters such as the physical and chemical properties of soil, rice productivity, and plant nutrient uptake in several soil types.

\section{Materials and Method}

The pot experiment was conducted in a net house, measuring $3.9 \times 2.8 \mathrm{~m}$ (length $\times$ width), located at Gondangrejo, Karanganyar, Central Java, Indonesia ( $\left.7^{\circ} 29^{\prime} 45^{\prime \prime} \mathrm{S}, 110^{\circ} 51^{\prime} 25^{\prime \prime} \mathrm{E}\right)$. The experiment was conducted from January to August 2019. The environmental conditions were maintained at an average temperature of approximately $28^{\circ} \mathrm{C}$ and rainfall of $2,588 \mathrm{~mm} \mathrm{y}^{-1}$. All pots $(28 \times 35 \mathrm{~cm}$ [diameter $\times$ height]) were filled up to $20-30 \mathrm{~cm}$ with various types of soil, namely, Inceptisols (subgroup: Typic Humudepts), Vertisols (subgroup: Typic Hapludalfs), and Alfisols (subgroup: Typic Hapludert). The physicochemical properties of each soil type, including soil texture, soil porosity, soil organic carbon, and soil $\mathrm{pH}$, are enlisted in Table 1. In addition, the pots contained urea $\left(\mathrm{CH}_{4} \mathrm{~N}_{2} \mathrm{O} ; 250 \mathrm{~kg} \mathrm{ha}^{-1}\right)$ and cow manure $\left(10,000 \mathrm{~kg} \mathrm{ha}^{-1}\right)(15.4 \mathrm{~g}$ urea and $5 \mathrm{~kg}$ [5.39 liters] cow manure per pot) (Santoso, 2014; Susilawati \& Purwoko, 2012). The cow manure was applied 1 week before transplanting, whereas urea was applied 2 weeks after transplanting.

In this study, the SALIBU and SINGGANG rice ratoon systems were used, which originated from Sumatra and Java, respectively. The rice cultivars used were Pandan Wangi and Mekongga. Harvesting was carried out after 230 days in the conventional system, and the first ratoon was harvested after 185 days. Each pot contained 12 paddy seedlings, and five samples were randomly selected for observation. The parameters were observed after the second harvesting and were not accumulated after the first harvesting. Hence, a completely randomized design was used to assess the three factors: soil types (B), ratoon types (P), and cultivar types ( $T$ ). In detail, the characteristics of the conventional and SINGGANG and SALIBU systems are presented in Table 2. In this study, we used 18 treatment combinations and three replicates, supported by laboratory analysis such as agronomic parameters and soil properties. Observations were made at a depth of 10-15 cm from the soil surface. Soil properties such as permeability and $\mathrm{pH}$ were analyzed according to (Sparks et al., 2020) and (Dane \& Topp, 2020), i.e., soil permeability was measured using the permeameter method (Dane \& Topp, 2020) and soil pH was measured using a digital $\mathrm{pH}$ meter (Oakton waterproof 30) (Sparks et al., 2020). Soil porosity was calculated from the ratio of bulk density and particle density (Dane \& Topp, 2020). Soil organic matter was measured using the Walkley and Black method (Bahadori \& Tofighi, 2016).

Table 1. Initial soil properties of each soil type (referred from USDA classification)

\begin{tabular}{|c|c|c|c|c|c|c|c|c|}
\hline $\begin{array}{l}\text { Soil } \\
\text { Type }\end{array}$ & Texture & $\begin{array}{l}\text { Clay } \\
(\%)\end{array}$ & $\begin{array}{l}\text { Silt } \\
(\%)\end{array}$ & $\begin{array}{l}\text { Sand } \\
(\%)\end{array}$ & $\begin{array}{l}\text { Soil Porosity } \\
\text { (\%) }\end{array}$ & $\begin{array}{c}\text { Soil Organic Carbon } \\
(\%)\end{array}$ & $\begin{array}{c}\text { Soil } \\
\text { Permeability } \\
\left(\mathrm{cm}^{3} \mathrm{~h}^{-1}\right)\end{array}$ & $\begin{array}{c}\text { Soil } \\
\mathrm{pH}\end{array}$ \\
\hline Inceptisols & Sandy Clay Loam & 25.44 & 15.22 & 59.34 & 46.043 & 2.041 & 14.273 & 6.01 \\
\hline Alfisols & Sandy Clay & 39.04 & 14.42 & 46.54 & 42.364 & 1.808 & 12.019 & 5.71 \\
\hline Vertisols & Clay & 50.27 & 28.84 & 20.88 & 39.133 & 2.253 & 9.127 & 6.22 \\
\hline
\end{tabular}

Table 2. Differences between the conventional, SINGGANG, and SALIBU planting systems

\begin{tabular}{|c|c|c|c|}
\hline \multirow{2}{*}{ Item } & \multicolumn{3}{|c|}{ Planting System } \\
\hline & Conventional & SINGGANG & SALIBU \\
\hline Irrigation & $\begin{array}{l}500 \text { milliliter every day, } \\
\text { total } 115 \text { liters }\end{array}$ & $\begin{array}{l}500 \text { milliliter every } 3 \text { days, } \\
\text { total } 30.83 \text { liters }\end{array}$ & $\begin{array}{l}500 \text { milliliter every } 3 \text { days (with special } \\
\text { treatment } 2 \text { weeks before and } 2 \text { weeks } \\
\text { after harvesting, watering every day for } \\
\text { flooded, total } 44.83 \text { liters) }\end{array}$ \\
\hline Weeding & Every 2 weeks & no weeding & Every week \\
\hline Harvesting & $\begin{array}{l}\text { After } 115 \text { days (first } \\
\text { plant) + after } 115 \text { days } \\
\text { (second plant) }\end{array}$ & $\begin{array}{l}\text { After } 115 \text { days (mother plant) } \\
+ \text { after } 70 \text { days (ratoon plant) }\end{array}$ & $\begin{array}{l}\text { After } 115 \text { days (mother plant) + after } 70 \\
\text { days (ratoon plant) }\end{array}$ \\
\hline Cutting & No cutting & $5 \mathrm{~cm}$ above from soil surface & $5 \mathrm{~cm}$ above from soil surface \\
\hline
\end{tabular}


The agronomic parameters that were observed after the second harvesting and were not accumulated with the first harvesting included the dry matter weight, dry yield weight, productive tiller number, and 1,000-grain weight. The nutrient uptake parameters that were observed after the second harvesting and not accumulated after the first harvesting included the nitrogen uptake measured using the Kjeldahl method with spectrophotometer, phosphorus uptake measured using the Olsen method with spectrophotometer, and potassium uptake measured using ammonium acetate extraction with atomic absorption spectrophotometer (Soil Survey Staff, 2014; Sparks et al., 2020). The details of the combination treatments are shown below:

\author{
РОВ0т0: Conventional, Inceptisols, Pandan Wangi \\ P1B0T0: SINGGANG, Inceptisols, Pandan Wangi \\ P2B0T0: SALIBU, Inceptisols, Pandan Wangi \\ P0B1T0: Conventional, Alfisols, Pandan Wangi \\ P1B1T0: SINGGANG, Alfisols, Pandan Wangi \\ P2B1T0: SALIBU, Alfisols, Pandan Wangi \\ P0B2T0: Conventional, Vertisols, Pandan Wangi \\ P1B2T0: SINGGANG, Vertisols, Pandan Wangi \\ P2B2T0: SALIBU, Vertisols, Pandan Wangi \\ РОВ0T1: Conventional, Inceptisols, Mekongga \\ P1B0T1: SINGGANG, Inceptisols, Mekongga \\ P2B0T1: SALIBU, Inceptisols, Mekongga \\ P0B1T1: Conventional, Alfisols, Mekongga \\ P1B1T1: SINGGANG, Alfisols, Mekongga \\ P2B1T1: SALIBU, Alfisols, Mekongga \\ POB2T1: Conventional, Vertisols, Mekongga \\ P1B2T1: SINGGANG, Vertisols, Mekongga \\ P2B2T1: SINGGANG, Vertisols, Mekongga
}

The arithmetic mean values with standard errors were calculated and analyzed using the SPSS statistical software (version 20). To compare the differences in all parameters among the treatments, ANOVA was used to detect the effects of soil types, rice ratoon systems, cultivar types, and their interactions on dependent variables. Then, Duncan's multiple range test was used for multiple comparisons between all treatments at 0.05 probability level $(p \leq 0.05)$.

\section{Results}

Table 3 shows the effects of the planting system, soil types, and plant cultivars on the selected soil parameters, agronomic parameters, and nutrient uptake parameters. As shown in Table 3, the soil pH was between 5.16 and 6.65 among all treatments, indicating that the soil $\mathrm{pH}$ increased after implementation of the combination treatments. The soil organic carbon was the highest $(2.59 \%)$ under P2B2T1 treatments, whereas it was the lowest $(1.77 \%)$ under the P0B1T1 treatment. In addition, it was observed that the physical property of soil porosity under the P1B0T0 treatment was the highest (up to $48.89 \%$ ) among all treatments and $2 \%$ higher than the initial condition, as shown in Table 1. On the contrary, soil porosity was the lowest and decreased under the POB2T1 treatment ( $30.14 \%$ and up to $9 \%$, respectively). Concerning soil permeability, the P1B0TO treatment resulted in permeability of $17.67 \mathrm{~cm}^{3} \mathrm{~h}^{-1}$ (highest), while the POB2T1 treatment resulted in permeability of $8.73 \mathrm{~cm}^{3} \mathrm{~h}^{-1}$ (lowest).

Table 3 shows that the treatments resulted in significant differences in the agronomic parameters, such as dry matter weight, dry yield weight, productive tiller number, and 1,000grain weight. In addition, P0B1T0 has the highest dry matter weight (96.57 g per plant clump), whereas P1B1T1 has the lowest (31.83 g per plant clump). POB1T0 treatment was similar to other treatments, whereas, the P1B1T1 treatment differed from all treatments, except P2B1T1. On the other hand, the dry yield weight was the highest (11.33 tons ha ${ }^{-1}$ ) under the P0B1T0 treatment, which was significantly different from the other treatments, whereas the lowest ( 3.73 tons ha ${ }^{-1}$ ) was that under the P1B1T1 treatment, which was significantly different from the other treatments.

The productive tiller number in the POB1T0 treatment (20.87) was the highest and significantly different from other treatments. The lowest productive tiller number (5.23) was from under the P1B1T1 treatment and significantly different others. The 1,000-grain weight was the highest $(26.7 \mathrm{~g})$ under the POB2TO treatment and the lowest $(16.4 \mathrm{~g})$ under the P1B1T1 treatment. For calculating plant nutrient uptake, the leaf, stem, straw, and grain of rice were considered. Table 3 shows that the conventional system in all soil types and cultivars was higher in productivity than SINGGANG and SALIBU.

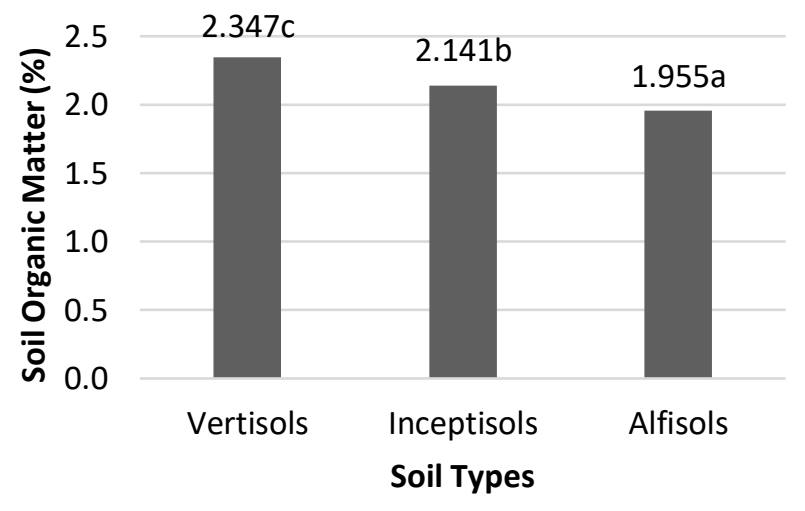

Figure 1. Soil Organic Matter vs Soil Types

(Note: Means followed by the same letter are not significantly different at $\alpha=0.05$ )

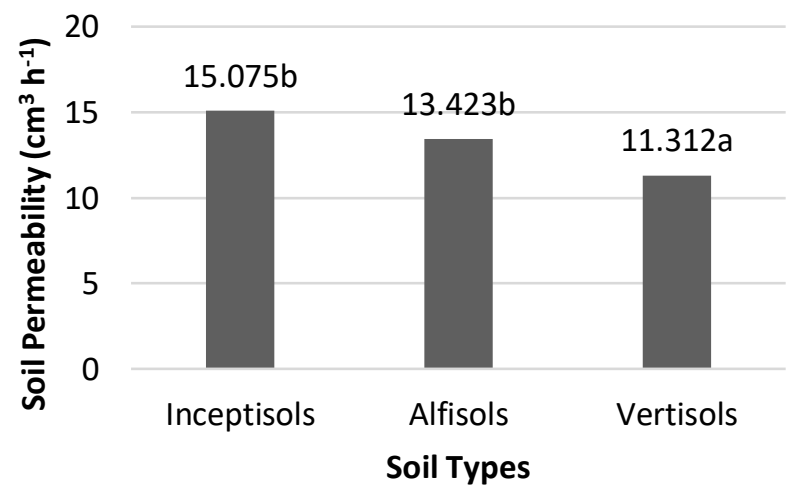

Figure 2. Soil Permeability vs Soil Types

(Note: Means followed by the same letter are not significantly different at $\alpha=0.05$ ) 


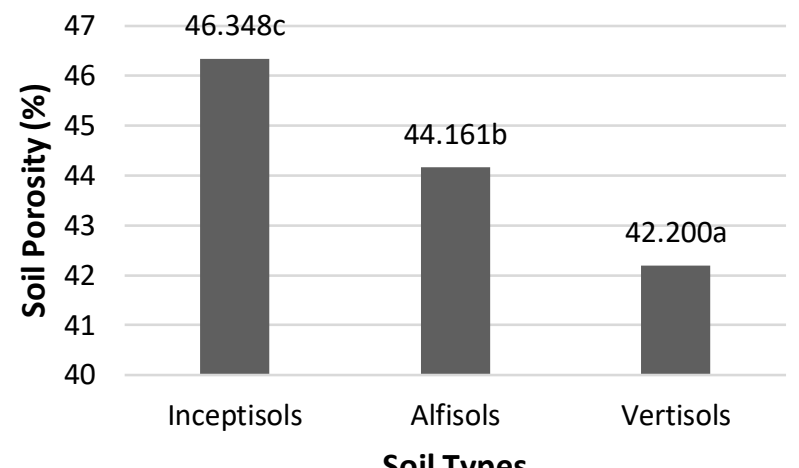

Soil Types

Figure 3. Soil Porosity vs Soil Types

(Note: Means followed by the same letter are not significantly different at $\alpha=0.05$ )

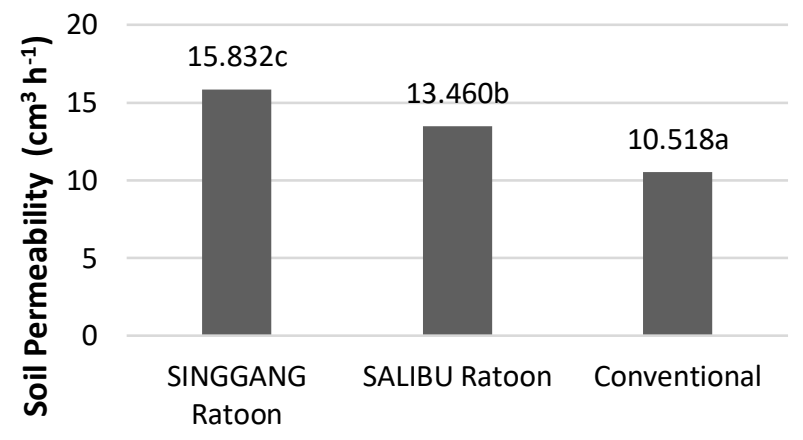

Planting System

Figure 4. Soil Permeability vs Planting System

(Note: Means followed by the same letter are not significantly different at $\alpha=0.05$ )

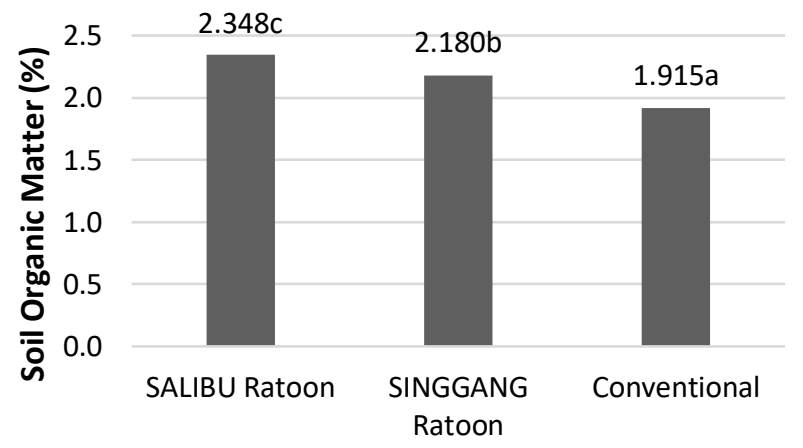

Planting System

Figure 5. Soil Organic Matter vs Planting System

(Note: Means followed by the same letter are not significantly different at $\alpha=0.05$ )

The nitrogen and phosphorus uptakes at Р0В0T0, Р1В0T0, and Р2В0T0 were 359.25 and 61.37, 259.45 and 40.74, and 294.79 and $48.46 \mathrm{mg}$ per plant clump, respectively.

Figures 1, 2, and 3 show the selected soil properties (soil organic matter, soil permeability, and soil porosity) observed in each soil type. It can be seen in Figure 1 that organic matter was significantly higher in Vertisols (2.347\%) and Inceptisols (2.141\%) and it was lower in Alfisols (1.955\%). Similarly, soil permeability (Figure 2) was high in Inceptisols and Alfisols (15.075 and $13.423 \mathrm{~cm}^{3} \mathrm{~h}^{-1}$, respectively) and low in Vertisols

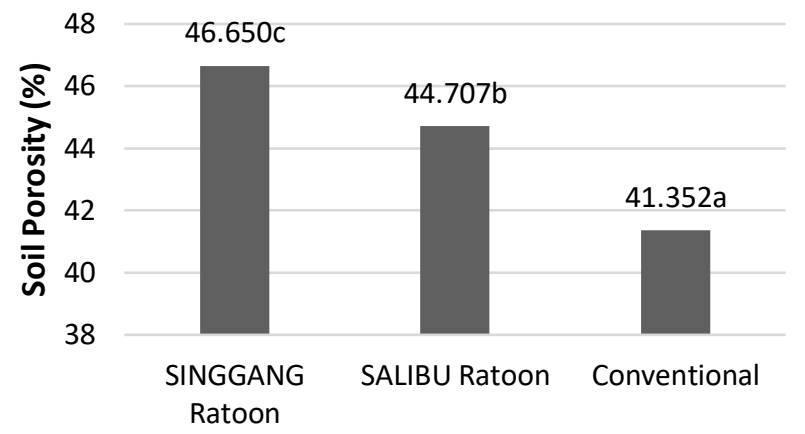

Planting System

Figure 6. Soil Porosity vs Planting System

(Note: Means followed by the same letter are not significantly different at $\alpha=0.05$ )

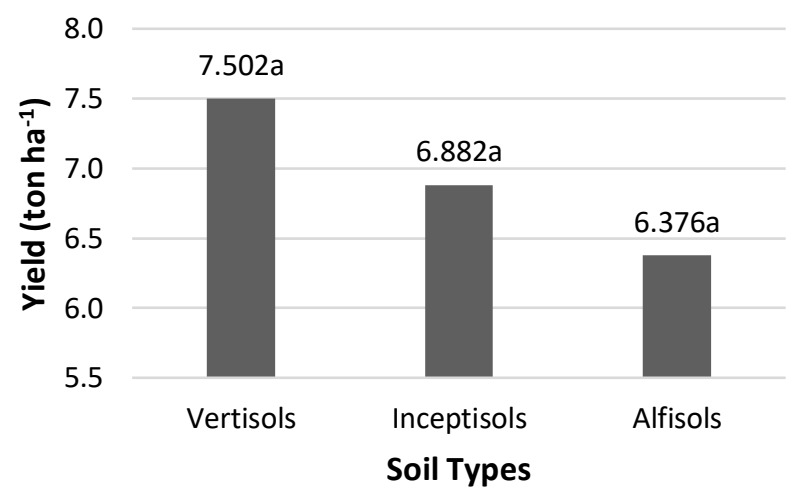

Figure 7. Yield vs Soil Types

(Note: Means followed by the same letter are not significantly different at $\alpha=0.05$ )

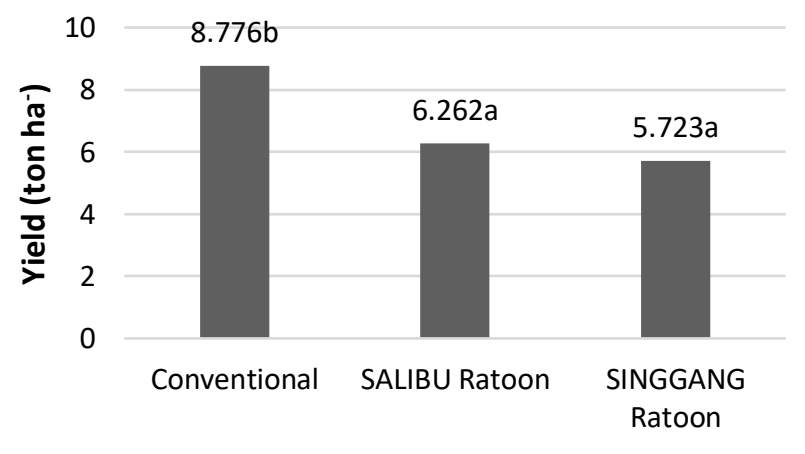

Figure 8. Yield vs Planting System

(Note: Means followed by the same letter are not significantly different at $\alpha=0.05$ )

$\left(11.312 \mathrm{~cm}^{3} \mathrm{~h}^{-1}\right)$. On the other hand, soil porosity increased in the order: Vertisols (42.200\%) < Alfisols (44.161\%) < Inceptisols (46.348\%).

Figures 4, 5, and 6 illustrate the selected soil properties that resulted from the planting system. It can be seen in Figure 4 that soil permeability was significantly high under the SINGGANG ratoon system $\left(15.832 \mathrm{~cm}^{3} \mathrm{~h}^{-1}\right)$, followed by the SALIBU ratoon system $\left(13.460 \mathrm{~cm}^{3} \mathrm{~h}^{-1}\right)$ and the conventional system $\left(10.518 \mathrm{~cm}^{3} \mathrm{~h}^{-1}\right)$. 
Table 3. The effects of planting system, soil types, and plant cultivars on selected soil parameters, agronomic parameters, and nutrient uptake parameters

\begin{tabular}{|c|c|c|c|c|c|c|c|c|c|c|c|}
\hline \multirow[b]{2}{*}{ Treatment } & \multicolumn{4}{|c|}{ Soil Parameters } & \multicolumn{4}{|c|}{ Agronomic Parameters } & \multicolumn{3}{|c|}{ Nutrient Uptake Parameters } \\
\hline & $\begin{array}{l}\text { Soil Porosity } \\
\text { (\%) }\end{array}$ & $\begin{array}{l}\text { Soil Organic Carbon } \\
(\%)\end{array}$ & $\begin{array}{l}\text { Soil Permeability } \\
\qquad\left(\mathrm{cm}^{3} \mathrm{~h}^{-1}\right)\end{array}$ & Soil pH & $\begin{array}{c}\text { Dry Matter } \\
\text { Weight } \\
\text { (gr/clump } \\
\text { of plant) }\end{array}$ & $\begin{array}{l}\text { Dry Yield } \\
\text { Weight } \\
\text { (ton/ha) }\end{array}$ & $\begin{array}{l}\text { Productive } \\
\text { Tiller } \\
\text { Number }\end{array}$ & $\begin{array}{c}\text { 1,000- } \\
\text { Grain } \\
\text { Weight } \\
\text { (gr) }\end{array}$ & $\begin{array}{l}\text { Nitrogen } \\
\text { (mg/clump } \\
\text { of plant) }\end{array}$ & $\begin{array}{l}\text { Phosphorus } \\
\text { (mg/clump } \\
\text { of plant) }\end{array}$ & $\begin{array}{c}\text { Potassium } \\
\text { (mg/clump } \\
\text { of plant) }\end{array}$ \\
\hline РОВ0ТО & $43.17 d$ & $1.86 a b$ & $12.13 \mathrm{f}$ & $5.85 \mathrm{~b}$ & 63.18 efg & 7.49 ef & $13.89 \mathrm{i}$ & $25.8 \mathrm{hi}$ & $359.25 \mathrm{k}$ & $61.37 \mathrm{jk}$ & $332.43 \mathrm{f}$ \\
\hline Р1В0т0 & $48.89 \mathrm{k}$ & $2.19 \mathrm{~d}$ & $17.67 \mathrm{k}$ & $6.18 \mathrm{efg}$ & $44.96 \mathrm{~b}$ & $5.54 \mathrm{bcd}$ & 7.76 cde & 22.0 cde & $259.45 \mathrm{~d}$ & $40.74 \mathrm{ab}$ & 303.55 a \\
\hline Р2В0Т0 & $46.78 \mathrm{ij}$ & $2.38 \mathrm{e}$ & $15.38 \mathrm{i}$ & $6.37 \mathrm{~h}$ & 55.54 cde & $6.18 \mathrm{~d}$ & $8.65 \mathrm{f}$ & $22.8 \mathrm{def}$ & $294.79 \mathrm{f}$ & 48.46 def & $312.18 \mathrm{c}$ \\
\hline P0B1T0 & $41.61 \mathrm{~b}$ & $1.78 \mathrm{a}$ & $10.43 c$ & $5.61 \mathrm{a}$ & $96.57 \mathrm{i}$ & $11.33 \mathrm{i}$ & $20.87 k$ & $25.5 \mathrm{hi}$ & $317.50 \mathrm{i}$ & $55.66 \mathrm{hi}$ & $385.92 \mathrm{~h}$ \\
\hline P1B1T0 & $46.38 \mathrm{~h}$ & $1.97 \mathrm{bc}$ & $16.32 \mathrm{j}$ & $5.95 \mathrm{bc}$ & $46.28 \mathrm{bc}$ & $4.92 \mathrm{~b}$ & $6.89 \mathrm{~b}$ & $21.2 \mathrm{bc}$ & $254.78 \mathrm{c}$ & $41.24 \mathrm{ab}$ & 429.021 \\
\hline P2B1T0 & $44.23 \mathrm{f}$ & $2.13 \mathrm{~d}$ & $13.34 \mathrm{~g}$ & $6.14 \mathrm{def}$ & $49.61 \mathrm{bcd}$ & $6.07 d$ & 8.50 ef & $21.7 \mathrm{~cd}$ & $309.46 \mathrm{~g}$ & 50.84 ef & $411.51 \mathrm{j}$ \\
\hline РОВ2Т0 & 39.17 a & $2.09 \mathrm{~cd}$ & $9.13 \mathrm{~b}$ & $6.01 \mathrm{~cd}$ & $66.64 \mathrm{fg}$ & $8.34 \mathrm{~g}$ & $15.68 \mathrm{j}$ & $26.7 \mathrm{i}$ & $362.13 \mathrm{k}$ & $61.72 \mathrm{k}$ & $452.09 n$ \\
\hline Р1B2T0 & $44.96 \mathrm{~g}$ & $2.40 \mathrm{e}$ & $13.49 \mathrm{gh}$ & $6.39 \mathrm{~h}$ & 56.82 cdef & 7.37 ef & $10.31 \mathrm{~g}$ & $24.3 \mathrm{fgh}$ & $233.82 \mathrm{~b}$ & $48.01 \mathrm{de}$ & 429.14 I \\
\hline Р2B2T0 & $42.81 \mathrm{c}$ & 2.51 ef & $11.67 \mathrm{e}$ & $6.69 \mathrm{i}$ & $66.09 \mathrm{fg}$ & $7.98 \mathrm{fg}$ & $11.17 \mathrm{~h}$ & $24.6 \mathrm{gh}$ & 280.97 e & $54.13 \mathrm{gh}$ & $430.14 \mathrm{Im}$ \\
\hline Р0В0T1 & $43.65 \mathrm{e}$ & $1.88 a b$ & $12.23 \mathrm{f}$ & $5.84 \mathrm{~b}$ & $83.16 \mathrm{~h}$ & $10.03 \mathrm{~h}$ & $14.05 i$ & 20.8 bc & $325.08 \mathrm{j}$ & $58.51 \mathrm{ij}$ & $319.13 d$ \\
\hline Р1B0T1 & $48.61 \mathrm{k}$ & $2.18 \mathrm{~d}$ & $17.58 \mathrm{k}$ & $6.11 \mathrm{def}$ & 59.73 defg & 7.07 e & $9.90 \mathrm{~g}$ & $17.3 \mathrm{a}$ & $212.63 \mathrm{a}$ & $45.89 \mathrm{~cd}$ & $307.33 \mathrm{~b}$ \\
\hline Р2B0T1 & $46.98 \mathrm{j}$ & $2.36 \mathrm{e}$ & $15.46 \mathrm{i}$ & $6.33 \mathrm{gh}$ & $42.56 \mathrm{~b}$ & $4.97 b c$ & $6.97 b c$ & $17.7 \mathrm{a}$ & $313.58 \mathrm{~h}$ & $51.13 \mathrm{fg}$ & 324.84 e \\
\hline P0B1T1 & $41.36 \mathrm{~b}$ & $1.77 \mathrm{a}$ & $10.46 \mathrm{c}$ & $5.68 \mathrm{a}$ & 58.67 defg & $6.91 \mathrm{e}$ & $9.69 \mathrm{~g}$ & $21.4 \mathrm{bcd}$ & $328.02 \mathrm{j}$ & $62.98 \mathrm{k}$ & $344.38 \mathrm{~g}$ \\
\hline P1B1T1 & $46.63 \mathrm{hi}$ & $1.96 \mathrm{bc}$ & $16.47 \mathrm{j}$ & 5.92 bc & $31.83 a$ & $3.73 \mathrm{a}$ & $5.23 \mathrm{a}$ & $16.4 \mathrm{a}$ & $235.65 b$ & $40.28 a$ & $417.64 \mathrm{k}$ \\
\hline P2B1T1 & $44.75 \mathrm{~g}$ & $2.12 \mathrm{~d}$ & $13.52 \mathrm{~h}$ & $6.19 \mathrm{fg}$ & $41.68 \mathrm{ab}$ & $5.28 \mathrm{bc}$ & $7.40 \mathrm{bcd}$ & $16.9 a$ & $307.07 \mathrm{~g}$ & $51.48 \mathrm{fg}$ & 398.82 i \\
\hline Р0В2Т1 & 39.14 a & $2.10 \mathrm{~cd}$ & $8.73 \mathrm{a}$ & 6.03 cde & $68.51 \mathrm{~g}$ & $8.55 \mathrm{~g}$ & $11.97 \mathrm{~h}$ & $23.3 \mathrm{efg}$ & 319.87 i & $55.91 \mathrm{hi}$ & 482.98 o \\
\hline P1B2T1 & $44.43 \mathrm{f}$ & $2.39 \mathrm{e}$ & $13.46 \mathrm{gh}$ & $6.31 \mathrm{gh}$ & $46.48 \mathrm{bc}$ & $5.70 \mathrm{~cd}$ & $7.99 \mathrm{def}$ & 20.1 b & $232.82 \mathrm{~b}$ & 43.78 bc & $429.24 I$ \\
\hline P2B2T1 & $42.69 c$ & $2.59 \mathrm{f}$ & $11.39 \mathrm{~d}$ & $6.65 i$ & $62.12 \mathrm{efg}$ & $7.08 \mathrm{e}$ & $9.92 \mathrm{~g}$ & 20.7 bc & $293.85 f$ & 50.31 ef & $432.94 \mathrm{~m}$ \\
\hline
\end{tabular}

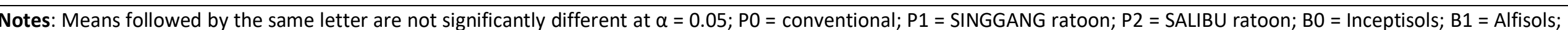
$\mathrm{B} 2=$ Vertisols; $\mathrm{TO}=$ Pandan Wangi cultivar; $\mathrm{T} 1=$ Mekongga cultivar 
Table 4. Pearson's correlation analysis of agronomic parameters with plant nutrient uptake and soil properties

\begin{tabular}{|c|c|c|c|c|c|c|}
\hline \multirow[b]{2}{*}{ Parameters } & \multicolumn{2}{|c|}{ Plant Nitrogen Uptake } & \multicolumn{2}{|c|}{ Plant Phosphorus Uptake } & \multicolumn{2}{|c|}{ Plant Potassium Uptake } \\
\hline & Pearson's Correlation & P Value & $\begin{array}{l}\text { Pearson's } \\
\text { Correlation }\end{array}$ & P Value & $\begin{array}{l}\text { Pearson's } \\
\text { Correlation }\end{array}$ & P Value \\
\hline Dry Matter & 0.749 & $<0.01 * *$ & 0.817 & $<0.01 * *$ & 0.719 & $<0.01^{* *}$ \\
\hline Dry Yield & 0.448 & $<0.01 * *$ & 0.658 & $<0.01 * *$ & 0.564 & $<0.01^{* *}$ \\
\hline Productive Tiller Number & 0.533 & $<0.01 * *$ & 0.644 & $<0.01 * *$ & 0.558 & $<0.01^{* *}$ \\
\hline 1,000-Grain Weight & 0.477 & $<0.01 * *$ & 0.499 & $<0.01 * *$ & 0.439 & $<0.01^{* *}$ \\
\hline
\end{tabular}

Notes: ${ }^{* *}$ highly significant ( $p$ value $\left.<0.01\right) ;{ }^{*}$ significant ( $p$ value $\left.=0.01-0.05\right) ;{ }^{\text {ns }}$ not significant $(p$ value $>0.05)$

Meanwhile, Figure 5 shows the significant decline in organic matter in the order: SALIBU ratoon system $(2.348 \%)>$ SINGGANG ratoon $(2.180 \%)>$ conventional $(1.915 \%)$. Soil porosity, shown in Figure 6, decreased in the order: SINGGANG ratoon (46.650\%) > SALIBU ratoon $(44.707 \%)>$ conventional (41.352\%).

Figures 7 and 8 show the rice yield from each soil type and planting system. Figure 7 represents that the highest yield was from Vertisols ( 7.502 tons $\mathrm{ha}^{-1}$ ), significantly higher than the yield from Inceptisols ( 6.882 tons ha ${ }^{-1}$ ) and Alfisols (6.376 tons $\left.\mathrm{ha}^{-1}\right)$. In the meantime, Figure 8 shows that the highest from the conventional system (8.776 tons ha $\left.{ }^{-1}\right)$, which is significantly higher than the other systems (SALIBU ratoon system, 6.262 tons ha ${ }^{-1}$; SINGGANG ratoon system, 5.723 tons ha $^{-1}$ [lowest]). Table 4 depicts the Pearson's correlation between agronomic parameters with plant nutrient uptake and soil properties. As shown in Table 4, the dry mater, dry yield, productive tillage number, and 1,000-grain weight significantly correlated with plant nitrogen, phosphorus, and potassium uptakes $(p<0.01)$.

\section{Discussion}

Both ratoon planting systems, SINGGANG and SALIBU, resulted in better soil properties, indicated by the higher soil porosity (Figure 6), soil organic matter (Figure 5), soil permeability (Figure 4), and soil pH (Table 3). However, since the ratoon planting system just maintains the stubble of the previous crop, it resulted in lower agronomic parameters and plant nutrient uptake (Table 3). Overall, the ratoon planting system positively affected soil properties; however, the system does not give good rice productivity. Plant varieties did not affect the observed parameters, but soil type affected the soil properties. Because of the limited availability of water, several varieties of rice plants showed differences, except for drought-resistant rice varieties (Zhang et al., 2017).

Compared with the conventional system, the soil porosity in the SINGGANG and SALIBU ratoon systems were $12.81 \%$ and $5.30 \%$ higher, respectively. On the other hand, the respective soil organic carbon, soil permeability, and soil $\mathrm{pH}$ under the SINGGANG and SALIBU ratoon planting systems were $13.83 \%$ and $22.58 \%, 50.52 \%$ and $31.14 \%$, and $5.25 \%$ and $9.52 \%$ higher than the conventional system. That is because the ratoon planting systems reduce soil tillage, which may break the soil aggregate (Aula et al., 2019). Hence, the ratoon cropping system maintains stability in the soil pores and soil water holding capacity and maintains soil permeability (Liu et al., 2014; Zhang et al., 2017). In another hand, the ratoon planting system maintains organic carbon soil. This is because the growth cycle of the ratoon plant does not start from seeds but grows from the stem of the mother plant; hence, the vegetative phase is cut, and its life cycle becomes shorter, and the harvest is faster (Liu et al., 2012). The organic carbon in soil can affect the soil $\mathrm{pH}$ because organic carbon can act as a chelating agent and bind elements that can cause soil acidity; thus, it functions as a buffer. Therefore, the soil $\mathrm{pH}$ is always close to neutral (Srivastava et al., 2009; Suwandi et al., 2012).

The agronomic parameters of dry matter weight and dry yield weight (Table 3 ) under SINGGANG and SALIBU were $34.50 \%$ and $27.28 \%$ and $34.81 \%$ and $28.66 \%$, respectively, lower than the conventional system. On the other hand, the parameters of productive tiller number and 1,000-grain weight (Table 3) under SINGGANG and SALIBU were $44.18 \%$ and $38.92 \%$, and $15.47 \%$ and $13.31 \%$, respectively, lower than the conventional system. That is because the ratoon system reduces the vegetative phase as the ratoon plants do not start from seeds. On the other hand, the harvest period of the ratoon systems is faster than the conventional system (Sanni et al., 2009; Zhang et al., 2017).

The plant nutrient uptake analysis showed that the nitrogen, phosphorus, and potassium in the SINGGANG and SALIBU ratoon systems are $28.96 \%$ and $10.54 \%, 27.01 \%$ and $13.98 \%$, and $26.48 \%$ and $12.14 \%$, respectively, lower than the conventional system. The plant nutrient uptake in the ratoon system is lower than the conventional system because the phenology of the ratoon system is shorter than that of the conventional system (Liu, 2012). On the other hand, the nitrogen uptake on ratoon plant is lower than the mother plant because nitrogen in ratoon has been used in the formation of ratoon shoot and tillers (Ling et al., 2019). The phosphorus and potassium uptake are distributed over the reproductive phase, hence the ratoon led to decreased seed size, seed weight, and grain yield because the duration of flowering and seed formation was very short. Hence, the ability of the plant to absorb nutrients from the soil is limited (Susilawati et al., 2012). Therefore, the level of rice productivity is proportional to the rate of plant nutrient uptake.

Soil properties inversely correlated with the yields from the SINGGANG and SALIBU ratoon systems. The yields obtained from the SINGGANG and SALIBU ratoon systems were lower, but the soil properties are better. This is caused by the shorter vegetative phase of the ratoon system (Fitri et al., 2019). On the other hand, the ratoon system can minimize soil tillage and reduce the time required for harvesting (Liu, 2012; Sanni et al., 2009; Zhang et al., 2017).

\section{Conclusion}

Our study showed that the interaction between rice ratoon systems and cultivars has a positive effect on the 
porosity, permeability, and soil $\mathrm{pH}$ in comparison to the conventional system. Moreover, the SINGGANG ratoon system has a positive effect on the physical properties of soil (porosity and permeability), and the SALIBU ratoon system has a positive effect on chemical properties $(\mathrm{pH}$ and organic carbon). We concluded that rice ratooning systems, such as SINGGANG and SALIBU, are effective for maintaining soil properties. In contrast, we showed that the agronomic parameters such as dry matter, dry yield, productive tiller number, and 1,000-grain weight were negatively affected by the ratoon systems. The nutrient uptake was also higher in the conventional than the ratoon system over soil types and cultivars. Lastly, further studies to clarify the yield performance of the SINGGANG and SALIBU systems are indispensable to generate reliable data for farmers.

\section{Declaration of Competing Interest}

The authors declare no competing financial or personal interests that may appear and influence the work reported in this paper.

\section{References}

Aula, L., Omara, P., Dhillon, J. S., Fornah, A., \& Raun, W. R. (2019). Influence of Applied Cattle Manure on Winter Wheat (Triticum aestivum L.) Grain Yield, Soil pH and Soil Organic Carbon. Communications in Soil Science and Plant Analysis, 50(16), 2056-2064. https://doi.org/10.1080/00103624.2019.1648664

Bahadori, M., \& Tofighi, H. (2016). A Modified Walkley-Black Method Based on Spectrophotometric Procedure. Communications in Soil Science and Plant Analysis, 47(2), 213-220. https://doi.org/10.1080/00103624.2015.1118118

Dane, J. H., \& Topp, C. G. (2020). Methods of soil analysis, Part 4: Physical methods (Vol. 20). John Wiley \& Sons. https://acsess.onlinelibrary.wiley.com/doi/book/10.2 136/sssabookser5.4

Fitri, R., Erdiman, Kusnadi, N., \& Yamaoka, K. (2019). SALIBU technology in Indonesia: an alternative for efficient use of agricultural resources to achieve sustainable food security. Paddy and Water Environment, 17(3), 403-410. https://doi.org/10.1007/s10333-019-00735-0

Imanudin, M. S., Bakri, B., \& Jelita, R. (2018). Ratoon Systems in Tidal Lowland: Study of Groundwater Dynamics and the Change of Nutrient Status on Rice Growth. SAINS TANAH-Journal of Soil Science and Agroclimatology, 15(2), 93-103. https://doi.org/10.15608/stjssa.v15i2.18928

Ling, X., Zhang, T., Deng, N., Yuan, S., Yuan, G., He, W., Cui, K., Nie, L., Peng, S., Li, T., \& Huang, J. (2019). Modelling rice growth and grain yield in rice ratooning production system. Field Crops Research, 241, 107574. https://doi.org/10.1016/j.fcr.2019.107574

Liu, E., Teclemariam, S. G., Yan, C., Yu, J., Gu, R., Liu, S., He, W., \& Liu, Q. (2014). Long-term effects of no-tillage management practice on soil organic carbon and its fractions in the northern China. Geoderma, 213, 379384.

https://doi.org/10.1016/j.geoderma.2013.08.021
Liu, K. (2012). Effects on source-sink of ratoon rice under simplified cultivation of different seeding stages. Soils, 44, 686-695.

Liu, K., Qin, J., Zhang, B., \& Zhao, Y. (2012). Physiological traits, yields and nitrogen translocation of ratoon rice in response to different cultivations and planting periods. African Journal of Agricultural Research, $7(16)$, 2539-2545. https://doi.org/10.5897/AJAR10.416

Oad, F., Sta Cruz, P., Memon, N., \& Oad, N. (2002). Rice ratooning management. Journal of Applied Sciences, 2(1), 29-35. https://doi.org/10.3923/jas.2002.29.35

Sanni, K., Ojo, D., Adebisi, M., Somado, E., Ariyo, O., Sie, M., Akintayo, I., Tia, D., Ogunbayo, S., \& Cisse, B. (2009). Ratooning potential of interspecific NERICA rice varieties (Oryza glaberrimax Oryza sativa). International Journal of Botany, 5(1), 112-115. https://doi.org/10.3923/ijb.2009.112.115

Santoso, M. B. (2014). BUDIDAYA PADI RATUN. Balai Besar Pelatihan Pertanian Binuang. https://sites.google.com/site/bbppbinuang/Artikel

Soil Survey Staff. (2014). Soil Survey Field and Laboratory Methods Manual. United States Department of Agriculture, Natural Resources Conservation Service. http://www.nrcs.usda.gov/Internet/FSE_DOCUMENT S/nrcs142p2_051546.pdf

Sparks, D. L., Page, A., Helmke, P., \& Loeppert, R. H. (2020). Methods of soil analysis, part 3: Chemical methods (Vol. 14). John Wiley \& Sons. https://acsess.onlinelibrary.wiley.com/doi/book/10.2 136/sssabookser5.3

Srivastava, T., Menhi, L., Singh, K., Archna, S., \& Pradip, K. (2009). Enhancing soil health and sugarcane productivity in a plant-ratoon system through organic nutrition modules in sub-tropics. Indian Journal of Agricultural Sciences, 79(5), 346-350. https://www.cabdirect.org/cabdirect/abstract/20093 150878

Susilawati, Purwoko, B. S., Aswidinnoor, H., \& Santosa, E. (2012). Peran Hara N, P dan K pada Pertumbuhan dan Perkembangan Ratun Lima Genotipe Padi. Jurnal Agronomi Indonesia (Indonesian Journal of Agronomy), 40(3). https://doi.org/10.24831/jai.v40i3.6820

Susilawati, S., \& Purwoko, B. S. (2012). Pengujian Varietas dan Dosis Pupuk untuk Meningkatkan Pertumbuhan dan Hasil Ratun-Padi di Sawah Pasang Surut. Jurnal Pengkajian dan Pengembangan Teknologi Pertanian, 15(1), 125622. http://ejurnal.litbang.pertanian.go.id/index.php/jpen gkajian/article/view/1265

Suwandi, S., Ammar, M., \& Irsan, C. (2012). Aplikasi Ekstrak kompos meningkatkan hasil dan menekan penyakit padi sistem ratun di sawah pasang surut Kabupaten Banyuasin. Jurnal Lahan Suboptimal: Journal of Suboptimal Lands, 1(2). http://www.jlsuboptimal.unsri.ac.id/index.php/jlso/a rticle/view/15 
Zhang, S., Hu, J., Yang, C., Liu, H., Yang, F., Zhou, J., Samson, B. K., Boualaphanh, C., Huang, L., Huang, G., Zhang, J., Huang, W., Tao, D., Harnpichitvitaya, D., Wade, L. J., \& Hu, F. (2017). Genotype by environment interactions for grain yield of perennial rice derivatives (Oryza sativa L./Oryza longistaminata) in southern China and Laos. Field Crops Research, 207, 62-70. https://doi.org/10.1016/j.fcr.2017.03.007 